\title{
The Well-Worn Book and the reading child: cultural and cognitive aspects of materiality in German children's literature
}

\author{
Hartmut Hombrecher ${ }^{1}$. Judith Wassiltschenko ${ }^{1}$
}

Published online: 28 August 2020

(c) The Author(s) 2020

\begin{abstract}
Children's books often feature complex material aspects. Despite that fact, little research has been done on questions of materiality in children's and youth books. The article aims at outlining the field of the materiality of historical German-language children's books. By analyzing historical author's pedagogical statements as well as the design of historical children's and youth fiction, the article summarizes different approaches concerning the materiality of children's books. Based on the historical development and the generic study on how children modify the materiality of their books, the article further investigates the book-as-object and emphasizes the child's point of view by scrutinizing the adult-culture book-toy distinction. It will become apparent that the specific forms of children's book reception emerge since the materiality of the book and its exploration present a new embodied experience. The specific reception forms can be embedded into a semiotic model of the textreader interaction in reference to Roland Barthes' concept of écriture and scription.
\end{abstract}

Keywords Children's literature $\cdot$ Children's culture $\cdot$ Storybooks $\cdot$ Reading culture Materiality $\cdot$ Embodiment

\section{Introduction}

Literary children's culture and its reception take place between the poles of the immaterial and the super-material. On the one hand, oral traditions and practices are associated with child-like literacy, writing, and language appropriation: fairy tales, read stories, sung songs, counting rhymes, jokes, wordplays, and soundplays. The purely auditory reception of literature is attributed mostly to children and performed for children by adults or by other children. On the other hand, there is already

Hartmut Hombrecher

hartmut.hombrecher@phil.uni-goettingen.de

1 Göttingen University, Göttingen, Germany 
literature for young children in text (and image). These works often feature complex materiality in the form of sumptuous illustration and the use of different textures, supporting material, and applications. Some of them challenge our idea of the book in its usual form. The visual appeal of most adult literature, in contrast, is limited-apart from the cover design. The form and thus (some aspects of) materiality become secondary for adult readers in comparison to the text. Bolter, in his remarks concerning printing, describes a classic medium for a mainly adult audience as a "medium that should disappear from a reader's conscious consideration" (Bolter 2001 , p. 43). The fact that children's literature in non-oral form is often more material-intensive than adult literature implies that material at various levels has a different and more important meaning for children's books. Firstly, production involves a wider range of materials. Secondly, the inclusion of the material continues within the narration. Thirdly, at the level of reception, which is not yet conventionalized in children, materiality influences the very access to literature or art (cf. Müller-Wille 2020). Nevertheless, research on the materiality of children's literature is very limited. This might be due to the fact that various apparently incompatible concepts of materiality exist in the humanities, while children's literature by its nature often requires interdisciplinary access. In fact, it is this greater emphasis on materiality that makes an interdisciplinary approach necessary, in the first place. Hence, in a first step, we will outline definitions of materiality in those scientific disciplines that deal with (children's) literature and books.

\section{Concepts of materiality}

Art history approaches to children's literature concentrate on the non-written/nonverbal artistic components of fiction that are mostly pictures or illustrations. In this context, questions about the production and nature of the underlying visual art are of importance (cf. Oetken 2008, p. 157 and 190, fn). This includes everything that renders the pictures haptic, such as oil painting and chalk drawing. Materiality also plays an important role in book science, book history, literary history, and the sociology of literature. The nature of the media reveals, for example, the degree of mechanization and innovation of the cultural and artistic spheres of the respective society (cf. Veryeri Alaca 2018, p. 60). The use of materials may offer an insight into the "prevailing definitions of childhood in a particular time and place" (Op de Beeck 2018, p. 19). In addition, book researchers found that the material influences how we read a text (alone or in groups, linear and sequential or situational and dialogical), which provides information on what kind of communicative culture we belong to (cf. Finkelstein and McCleery 2005, p. 121).

Furthermore, researchers who have been studying representations of literature in applied contexts, e.g. curating literature exhibitions, have dealt with the objectness of the book or books as material artifacts. Following a concept by Walter Benjamin, museological experts foreground the 'aura' of historically important works (cf. Kroucheva and Schaff 2013, pp. 9-13). Here, specific copies, such as first editions, manuscripts or typescripts, are often taken into consideration since in most cases visitors cannot read them in the usual ways that include touching, 
opening, marking, turning them around or taking them along. Instead, visitors are only allowed to look at the copies.

Linguists and philologists, in turn, often consider material in the context of literature exclusively as intellectual material, i.e. as linguistic units like phonemes or as semantic units (e.g. letter, syllable, word) or as poetic elements such as motifs and characters (cf. Bär et al. 2015, p. 7 and 11). Jerome McGann referred to 'hermeneutic material' as "a laced network of linguistic and bibliographical codes" (McGann 1991, p. 13). Nevertheless, some literary scholars, critics, and writers themselves cannot ignore the physical tangibility of the book and the relationship between text and carrier. This is shown by Aidan Chambers's notion, who reflects on "the book-as-object" (cited from Lambert 2018, p. 28), or a study by Field, who sees the temporal organization of picture narratives encoded in the spatial extent of the medium (cf. Field 2015, p. 166). To look at the relationship between the idea and the object means to understand the text together with its carrier as an artifact at which questions can be posed, which go beyond the scope of linguistic and philological aspects. At the same time, this means that philologists need to completely perceive by what kind of multi-dimensional and sensually tangible object the text is conveyed (cf. Finkelstein and McCleery 2005, p. 24). Pictorial and textual elements in picturebooks add up to one iconotext (cf. Hallberg 1982, p. 165) which allows complementary or contrasting readings. Similarly, material, illustrations, and text in combination create a specific meaning (cf. Maziarczyk 2013, p. 10). Material aspects of a book create an atmosphere that regulates the reader's expectations and responses to a narrative (cf. Veryeri Alaca 2018, p. 59), and for picture books it can be noted that "materiality in picture books was presented as a third narrative, alongside text and images" (ibid., pp. 66-67.; cf. also Rhedin 1992, p. 143). Montanaro Staples heads for a similar direction when she writes that "beautiful illustrations and exuberant mechanicals draw the reader into the story" (Montanaro Staples 2018, p. 187). In contrast to adult print media and literature, the material of children's literature is not supposed to disappear behind the text. According to researchers of children's literature, young recipients respond well to this synesthetic reading experience. At the same time, however, it involves the risk of diverting the reader's attention from the intended purpose of reception (cf. Kümmerling-Meibauer 2011, p. 3), which ideally fulfills several functions: It should train the handling of the literary object, the reader should find delight in the activity of reading, it should meet the child's horizons of reception that not yet or not only consists in conceiving letters forming a text. In the following, as the working definition of children's literature for this article serves the notion that children's literature is literature that is not only but mainly read by children and was therefore materialized by adults in a supposedly appealing form for children. In this study, the possibilities for philological research are explored to extensively examine the materiality of children's literature. In addition, the notion of the materiality of different disciplines should be brought together and expanded, as this is the only way to adequately study children's literature. We will argue that children's literature research must extend these previous notions of materiality with aspects of the reception. 


\section{Children's literature and material}

In the following, when we speak of the materiality of literature, we mean the physical foundations and conditions of writing, editing, embellishing, designing, producing and receiving literature. We mean the objectness and materiality of the text or image carrier and the commodity of children's literature as a cultural and economic product. We also include the author's/illustrator's corporality in the act of writing/ drawing (cf. Bäni Rigler 2019) as well as that of the reader's in the act of reading. This broad concept of literature, books, and materiality is analogous to the expansive and boundary-dissolving tendencies of children's literature, which also diversifies reception through its partly spectacular material production. Already in the 1990 s, Ulla Rhedin notes that current children's books are not just books with high image content:

Their greatest interest [...] demand the popular cultural picture books because they often challenge and almost go beyond the scope of the book medium itself. They come e.g. not only in paper and cardboard but also in fabric, wood or plastic, inviting not only to browsing activity but can also be rolled on wheels, can be folded and manipulated, bathed and combed. They are beeping, humming and playing, having pockets and puppets to develop the plot. They can generate smell and tactile sensations. They often have a theatrical character in a way that they expand in the room in three dimensions and thereby problematize in an interesting way the actual book medium. ${ }^{1}$

Similarly, Oetken sees "an overcoming of the two-dimensional surface through mirrors, flaps, and cut-outs into the vastness of three-dimensional space" and the demand for "interactive play" (Oetken 2008, p. 292). Roughly speaking, the more non-classical book materials are used and the more sensory stimulation is achieved in this way, the lower the targeted age of the recipient seems to be, which harmonizes with the above-mentioned observation that adult literature is materially rather sober. An example ${ }^{2}$ of a diverse usage of materials with the concurrent addressing of young readers is the Ri-Ra-Rasselbuch by Monika Neubacher-Fesser (1959-) for children from the age of 3 months. It consists of cardboard covered with soft fabric and a plastic rattle (Neubacher-Fesser 2018). It imitates the book's form by arranging four square pages, which are joined together like a book's binding, and their

\footnotetext{
1 "Sitt största intresse [...] har de populärkulturella bilderböckerna genom att de ofta utmanar och nära nog sprängar själva bokmediet. De förekommer t.ex. inte bara i papper och papp utan också i tyg, trä eller plast, inbjuder inte bara till bläddringsaktivitet utan kann också rullas fram på hjul, kann vikas och förändras, badas och kammas. De piper, brummar och spelar, har fickor och instoppsdockor at förändra handlingen med. De kann avkrävas lukter och taktila förnimmelser. De har ofta en teatral karaktär genom att de utvidgar sig i rummet i tre dimensioner och problematiserer därigenom på ett intressant sätt själva bokmediet." (Rhedin 1992, S. 14; our translation).

2 Due to our activities at the Georg-August-Universität Göttingen, we refer in this article several times to the resident Collection of historical children's and youth books. It consists of several collector's and scholar's libraries and covers a time range from around 1715 to 1990 . Except for Bertuch (1790) and Berner (2007), all the media discussed in this article are present in the collection. The Göttingen collection is cataloged, discussed, and presented in Mittler and Wangerin (2004), Wangerin (2011), Wassiltschenko (2018) and Hombrecher et al. (2019).
} 
front and back sides each show different motifs that fill the pages almost entirely. The Ri-Ra-Rasselbuch takes account of an understanding of child-like reading that goes far beyond the visual comprehension of letters and images and continues until a certain age. The central point of this article is that children's literature is dominated by a paradigm of overcoming and dissolving boundaries, which is analogous to other child-like practices. The cultural scientist Herrmann Bausinger, for example, postulates: "The real purpose of many forms of action in childhood culture is the dissolving of boundaries, questioning of all divisions, blockages, conclusions." 3 In an effort to understand children's culture, he advises "to pierce the frippery of the established culture for children and to capture in a lively way what constitutes the culture of the children." 4 This often consists of transformation, concatenation and free association of the encountered (cf. ibid., p. 13). Previous research (cf. Veryeri Alaca 2018, p. 59; Rhedin 1992, p. 14) and examples such as the Ri-Ra-Rasselbuch suggest that children's books should be perceived as multifunctional objects, namely, books and toys simultaneously. The connection between children's reading and play is also part of the dissolution of boundaries. How this is reflected on the producer's and recipient's side will be explained in Sects. 3 and 4. First of all, however, it is important to outline what different forms and materialities children's literature is presented in.

\section{Picture books}

It does not even have to be particularly spectacular books such as touch-and-feel books, sound books or the like. Even conventional forms, such as classic picture books, follow the pattern of dissolution of boundaries. Picture books often stand out because of their unusual, often large format, which makes the illustrations show to advantage. However, this implies that they must be read, transported and stored in a special way. Even picture books can be produced in great variety, as Veryeri Alaca exemplifies referring to the selected paper type: "paper, the major element of picture books, ranges from light to heavyweight, vellum to force, glossy to mat, and can involve alterations in how the colors appear, adding a tactile responsiveness, status, and value to the book" (Veryeri Alaca 2018, p. 65). These different possibilities of production can either support or disrupt the literary and pictorial narration and thus take on meaning on a material level (cf. ibid., p. 59). An example of the integration of materiality in literary studies is Messerli's study on the picturebook Die Menschen im Meer (1981) by Jörg Müller (1942-) and Jörg Steiner (1930-2013). With his study of the middle fold and its function within the story, he can show how the materiality of the book was included in the iconotextual narration and thus underlines its meaning (cf. Messerli 2005, pp. 9-19).

\footnotetext{
3 "Der eigentliche Sinn vieler Handlungsformen der Kinderkultur ist Entgrenzung, In-Frage-Stellen aller Einteilungen, Blockierungen, Abschlüsse.” (Bausinger 1987, p. 14; our translation).

4 "den Flitter der aufgesetzten Kultur für Kinder zu durchstoßen und lebendig einzufangen, was die Kultur der Kinder ausmacht” (Bausinger 1987, p. 12, emphasis in the original; our translation).
} 


\section{Expanding book formats}

Many types of children's books have the potential to stand out because of their materiality and to overcome conventional receptive behavior that is predominantly shaped by adult production and reception practices. Two examples will be given here. A picture book using the Accordion folding technique is Kommt mit zum Handwerksmann! with verses by Hanna Schachenmeier and illustrations by Marianne Scheel (1902-1941), which was published in 1942 in the first edition (Schachenmeier and Scheel [1944]; cf. Kayser 2011b, p. 150). It informs about traditional as well as contemporary-modern trades and crafts. The verso page after the main title shows a craftsman saying which is surrounded by the emblems of 28 professions. The image section extends over a $181 \mathrm{~cm}$ long paper strip, whose middle part is connected to the rear cardboard cover. The left and right protruding parts are folded in ever-narrower strips so that when opening the book, first a small tight city scene is visible. If one spreads the 18 folded sections either one at a time or at once, the small narrow town with narrow house fronts gradually turns into a generous street scene revealing handicraft businesses, shops, and figures during typical activities. Twelve short poems describe some of the professions and depicted trades. Through the Accordion or Concertina technique, which is similar to the Leporello, the city can be explored like on a tour, where you look around the corners of houses and then get new views, which can be disguised when the strips are shut again. Leporello and Accordion books attain the character of dissolution of boundaries by fanning the folded pages (cf. Kayser 2011a, pp. 144-146). Thus, a scenic representation is achieved, which is reminiscent of theatrical scenes as well as sequential media such as film, and thus suggests a certain dramaturgy. In addition, the medium multiplies its size the moment the narration is retrieved by looking at the sequence of scenes. Thus, the typical compactness of a book disappears and the medium becomes a fragile object, which is inconvenient to handle. This requires concentration and care. Another type of sprawling children's books are Wimmelbücher for which e.g. Ali Mitgutsch (1935-) has become well-known. Their size enhances the calculated visual confusion and overload at the illustration level, which is achieved by a plethora of co-plotted parallel scenes and characters. Therein lies the aesthetic charm of the Wimmelbücher. These are often textless and of large format, Das Riesenbilderbuch by Mitgutsch is even $61 \mathrm{~cm}$ high and $40 \mathrm{~cm}$ wide (one spread is $80 \mathrm{~cm}$ wide) and weighs about $2500 \mathrm{~g}$ (cf. Mitgutsch 1980). Since the many scenes shown on a double page are relatively small, one has to bring the large, hard-to-handle book closer to the face. The illustration fills the visual field almost completely so that the spread cannot be captured with a single look. The head has to be raised, lowered and turned to look at the big picture in quadrants. Thus, the other parts of the illustration are hidden again and again, although they are actually visible. As if one was looking at a rural or urban scene from a raised viewpoint or from an opposite window, the scenery is in front of the viewer, who, however, can only ever take a closer look at one section at a time. Rotraut Susanne Berner (1948-), who is also known as an illustrator of Wimmelbücher, brought together the two mentioned children's media types and published Wimmel-Leporello books, which 
accordingly combine some of the material effects of both types and form an even more sophisticated medium (e.g. Berner 2007).

\section{Pop-up books, playbooks, movable books}

Types of children's books that challenge the reader's need to test out the possibilities and limitations of the material are pop-up, playbook or movable books. Montanaro Staples, who studied pop-up books and movable books, characterizes them in summary:

A movable book, quite simply, is a book that has moving parts within its printed pages. They include illustrations and text that can be rotated, lifted, pushed or pulled from side to side, or in case of pop-ups, arise from the flat surface in three-dimensional form when a page is turned. [...] The ingenious mechanical paper devices in pop-ups and movable books are handmade creations designed to amaze, entertain, and educate the reader. (Montanaro Staples 2018, S. 180)

The reading audience has to leave a passive viewer-and-listener-role and instead, become active in order to exploit the material potential of the book. The images come to life and the action of the recipient tends to have a playing character. Some pop-up books get by with very little text or even have no textual elements, which is why they are not just another type of picture book, but a separate genre. They are all the more dependent on the imagination of the recipient, who must be descriptively and narratively active, which is why Montanaro Staples also speaks of "theater books" (ibid., p. 184). Pop-up books and movable books usually mimic the classic codex form through a rectangular format and middle fold, but then present their content very differently. Some move closer to the codex form by having pages to turn. Others move away from it and open three-dimensional coulisses when unfolding, with no other pages or text. Some historical examples will be given here and the principle will be explained. Lothar Meggendorfer (1847-1925) was at the time one of the internationally best-known creators of picture books and movable books. In his Lebende Bilder, he presents in short verses eight typical figures of the contemporary bourgeois everyday life on the verso pages which are then shown on the recto pages in moveable illustrations, including e.g. 'The Piano Player', 'The Tutor', and 'The Maiden Cook'. The humorous short poems all refer to the movements gained through drawable and sliding cardboard strips so that the stanza works like a user manual. For example, the poem for the Piano Player reads: "Playing the piano is difficult, / I notice it here in this young man; / He plays his piece with his head and with his hand-/ It is his luck that no one hears it."5 A piano player does not literally play the piano with his head, but in this context, the typical supportive rocking of the upper body is meant. This is achieved by the up-and-down movement of the

\footnotetext{
5 „Schwer ist das Spiel auf dem Klavier, / Ich seh’s an diesem Jüngling hier; / Mit Kopf und Hand spielt er sein Stück-/Daß man's nicht hört, das ist sein Glück." (Meggendorfer [c. 1873], p. [6]; our translation).
} 
head in which the integrated cardboard slide simultaneously moves the arms and hands up and down. Anticipating a childish temperament, Meggendorfer prefaces his intricate work with a ten-line foreword, also in rhymes, in which he admonishes the readership to treat the book carefully (Meggendorfer [c. 1873], p. [1]). Detailed in its pictorial design, simple in its technique and completely free of narrative texteven without a title-is a pop-up by Vojtěch Kubašta (1914-1992), which in this article will be referred to as Polarstation. Whether this is a book at all can be questioned because apart from the usual size of the children's book and the two cardboard covers, it has no further elements of a conventional codex (Kubašta [c. 1965]; cf. Kayser 2011c, p. 151). ${ }^{6}$ If you open the only spread that is also cover and back, a paper scenery unfolds, showing an airplane in front of a fantastic polar scene. Fantastic because two children perform dangerous specialized activities (flying, diving), because a lot of wild animals in the scene come together, even polar bears with penguins, and moreover a polar bear seems to operate a movie camera. The paper coulisses are illustrated on both sides so that each of the four visible sides gives a new perspective on the scene and allows for discovering more details each time. Of all the discussed children's media, Polarstation is thus far from a conventional book but also from a similar architectural toy such as a doll's house because the possibilities of use are very limited. It is to be understood as a paper artwork that fosters the imagination through looking and feeling the sensation of amazement. This leaves room for the recipient to invent an own narrative for the richly detailed scenery, although the distinct polar and expedition theme cannot be ignored.

\section{Book or toy?}

As mentioned above, with a closer look at the material level of children's literature, the book and reading concept is becoming more and more problematic because, for example, it has additional features that "enable the viewer to organize content via finger puppets, stickers, magnets, holograms, puzzles, removable folding structures for origami, or mirrors made out of aluminum foil to create reflective imagery" (Veryeri Alaca 2018, p. 63). In comparison to picture books and (unplayable) popups, playbooks expand the reception framework. The two- or three-dimensional images cannot only be viewed and discussed in conversation, but via tabs, strips, flaps, and punchings, an open and hidden stock of images can be theatrically called up and put into relation to the text if it exists (cf. Montanaro Staples 2018, p. 180). The reason for the multimaterial and functional design of books lies in the "entertaining and educational experience" (ibid., p. 187). The manipulation of the books is meant to stimulate the senses. However, the possible destruction of the book is not intended by the producer, as the foreword in Meggendorfer's Lebende Bilder shows. The reception is to expand on several activities, but in principle move within the framework of the given medium. That this approach to literary offerings for children is not a new phenomenon is shown by a children's book writer on the threshold

\footnotetext{
6 The Broward County Library, Florida has digitized a copy, which can be found at https://digitalarc hives.broward.org/digital/collection/kubasta/id/2587. Accessed June 12th 2019.
} 
of the Enlightenment to the Romanticism, who argued for a carefree, playful and creative use of books, and went quite far from a material perspective. In his nonfiction series Bilderbuch für Kinder (several volumes from 1790), F. J. Bertuch (1747-1822) defines the picture book in the first volume's preface as an "even more indispensable meuble as the cradle, a doll, or the hobbyhorse."7 Bertuch put picture books on the same level as typical children's toys. He goes on to say that the Bilderbuch should be left "for the use of the child entirely," and also includes the manipulation of the materiality of the book: "The child must be able to handle it completely as a toy; they must look at the illustrations anytime, they must illuminate it; yes, with the permission of the teacher, even cut the pictures and stick them on cardboard." 8 As becomes clear, maximum exposure to the material is encouraged but only under the supervision of educators and with careful use of the parts released from the book. The alleged free play to which the child readers are to be guided is thus also a directed one. Interesting in this context are two readers' addresses in the playbook The Magic Boat (1935) by Tom Seidmann-Freud (1892-1930), which is subtitled $A$ Book to Turn, Move and Alter. ${ }^{9}$ The book contains eight very different plays, some of which are linked to a story (e.g. The Wonderful House), while the connection of others to literature is represented by more or less well-known narratives or characters of popular and children's culture (e.g. Punch and Judy). Most games are provided with very precise instructions (e.g. The Counting Mountain). Two plays and their accompanying texts invite readers to become creative themselves. On the one hand, there is The Journey to the East Indies or The Punch and Judy Show, which is accompanied by 17 theatrical dialogues and stage directions, while on a two-dimensional stage eight figures can be called up via paper strips and combined into different pairs. At the end, there is the hint: "This is just a trial piece, the children can make for themselves amusing little sketches from the eight characters." (SeidmannFreud 1935, p. [10]). The creative play, therefore, works within the limits of the small mechanical paper stage with its eight figures. Another text in this book, on the other hand, encourages a freer adaptation of what has been found. In The Invisible Child, the story about the boy Nick, is narrated in a comic-like panel sequence. He walks around town unnoticed, playing tricks with an invisibility cap. To achieve this effect, the child character and other objects and animals, are printed in red. The book is enclosed with a red plastic foil. By placing this red foil over the page, the red printed parts become invisible while the remaining blue printed illustrations remain

\footnotetext{
7 „,noch unentbehrlicheres Meuble als die Wiege, eine Puppe, oder das Steckenpferd“ (Bertuch 1790, p. [3], emphasis in the original; our translation).

8 ,dem Kinde ganz zum Gebrauche“; „,Das Kind muss damit völlig umgehen können wie mit einem Spielzeuge; es muss darinn zu allen Stunden bildern, es muss es illuminiren, ja, sogar mit Erlaubniss des Lehrers, die Bilder ausschneiden und auf Pappendeckel kleben dürfen." (Bertuch 1790, p. [5]; our translation).

9 The book was first released in 1929 under the title Das Zauberboot. Ein Bilderbuch zum Drehen, Bewegen und Verwandeln (Das neue Wunderhaus) by Herbert Stuffer in Berlin in German and in 1935 published in Englisch by the same publisher. This article was based on the English edition. On the culture blog Brain Pickings animations show some of the moving plays in The Magic Boat, but from a later reprint edition. https://www.brainpickings.org/2015/02/18/the-magic-boat-tom-seidmann-freud/ Accessed 10 June 2019.
} 
visible. At the end of the play text, there is the invitation: "Clever children can try and make pictures of these for themselves." (ibid., pp. [4-5]). The same effects can actually be achieved with pens in red and other colors if one uses the book's red foil as an aid.

It has become clear to this point that children's literature since its inception, while using a material-intensive design, has followed the artistic and poetic principle of dissolution of boundaries that is firmly anchored in children's culture due to its inception through a material-intensive design. Since the books have a toy-like character, they invite further uses as well as a synaesthetic reception. However, this dissolution of boundaries again runs in the context and with the material possibilities of the medium which leads to a paradox. The artifacts call for very diverse use but often provide a desired or intended way of reception. In audience addresses and paratexts, authors of children's literature have occasionally expressed the hope that child recipients pick up on the playful handling and the aesthetics of dissolution of boundaries and continue it autonomously, but this is undermined again by (para-) textual or material guidance. Bausinger's idea of the unbounding tendency in childish cultural appropriation can also be found in children's books of various forms and materials. However, the notion of child-like desire for autonomously overcoming the encounter expressed by him is often neglected by adult producers of children's media. In the further course of the article, we will discuss if and where independent access of children to literature can be determined. In contrast to the previously shown forms of reception, children explore multiple ways to receive their books in manners that are unintended by the author or the publisher.

\section{Child-like enhancement of materiality}

Some of these manners of reception are also common in adults, as there are owner's and text marks, bookplates, and dedications. Most of these receptions interfere with the materiality of books in consequence of personalization or a working process. Furthermore, one should consider specific interferences that occur when children deal with children's books, such as the mentioned transformation of the book into a toy, the modification of illustrations, the individual reference to illustrations, the addition of text, and the modification of the book block or case.

It is to be assumed that the transformation into a toy is particularly common in young children. Usually, young children do not recognize books (at least not solely) as objects with a specific, intended manner of reception (cf. Kümmerling-Meibauer and Meibauer 2018, p. 393). Such a reception is due to the fact, that children up until school age depend on adults reading texts to them. When young children are alone with their books, a reading reception cannot function properly. It would seem that a reception appropriate to adults could be realized by simply looking at the book's illustrations. In fact, as with other objects, young children tend to play with books under these circumstances. The traces of children's reception in picture books of the Göttingen Collection of Historical Children's and Youth Literature suggest that a non-transforming perception appears to be unsatisfactory for many children. Books are not yet seen as reading-things but as play-things (cf. rudimentarily already Bauer 
van Wechem 1988, p. 58). It seems to be important for the playful understanding of the object that books are grasped in the literal sense as well.

The transformation of a book into a toy sometimes occurs even at an older age. In many of these cases, skimming the book's pages and flipping the book open randomly is of major importance: Even for young adults, a transformation of books into oracles or a game of truth or dare can be observed. ${ }^{10}$

In fact, modifications of the materiality are also accomplished in cases where illustrations are in the center of the child's attention. The modification of the book's materiality is based on the child's perception of books in general: children usually have not yet developed an image of books as cultural artifacts that are worth protecting. A child's handling of books might seem somewhat wanton to adults, who generally perceive the materiality of a book only as a text medium. As could be seen, this can be tied to totally different reception interests and ideas of an appropriate reception.

A cultural artifact worth protecting - at least from our current perspective-is Der rote Wunderschirm [i.e. The red wondrous umbrella]: The filigreed and sophisticatedly illustrated tale was anonymously published in (1890) in Neuruppin. It tells the story of two siblings traveling in a red umbrella to search for their emigrated parents. The umbrella itself is likewise wondrous as it protects the children, it provides food, and is able of different kinds of locomotion. Especially the illustrations of the Wunderschirm are an example of the dissolution of boundaries in this context. They "go beyond [...] these functional aspects of the 'Wondrous umbrella': they open a vague space for fantasy." "11 Today, only three copies of the book are known, one of which is part of the Göttingen Collection of Historical Children's and Youth Literature. In this copy, many child-like reception traces can be found. Especially the illustrations were amplified using pen and ink drawings. For instance, the sun that already exhibits features of a face was anthropomorphized with hair and a body (cf. Fig. 1). Such tendencies of anthropomorphization of animals or inanimate objects appear frequently in paintings by children, e.g. with the 'corner sun' which is often drawn with a face. In the case of the mentioned Wunderschirm illustration, the recipient seems to have located the newly emerged sun character in a more graspable space by having drawn a ladder.

Apart from graphic additions, there are also spaces that have been painted in. Thereby mostly white and pale spaces are painted over with brighter colors, and sometimes there are also color modifications. In the case of a Göttingen Collection's copy of Lurchi, even neon colors are used (cf. Fig. 2). They were implemented quite precisely and partly used in a way that they intensify already existing colors: pale blue becomes bright blue, pale red becomes bright red, etc. This detailed manner of coloring in can be contrasted with extensive 'scribblings'. They can be found for instance in the Göttingen copy of the classic children's

\footnotetext{
${ }^{10}$ Books functioning as oracles can also be shown for ancient pagan-Germanic and later Christian times (cf. Krutzler 2011, p. 163).

11 ,überschreiten [...] diese funktionalen Aspekte des ,Wunderschirms“: Sie öffnen einen unbestimmten Phantasieraum“ (Rumpf 2011; our translation).
} 


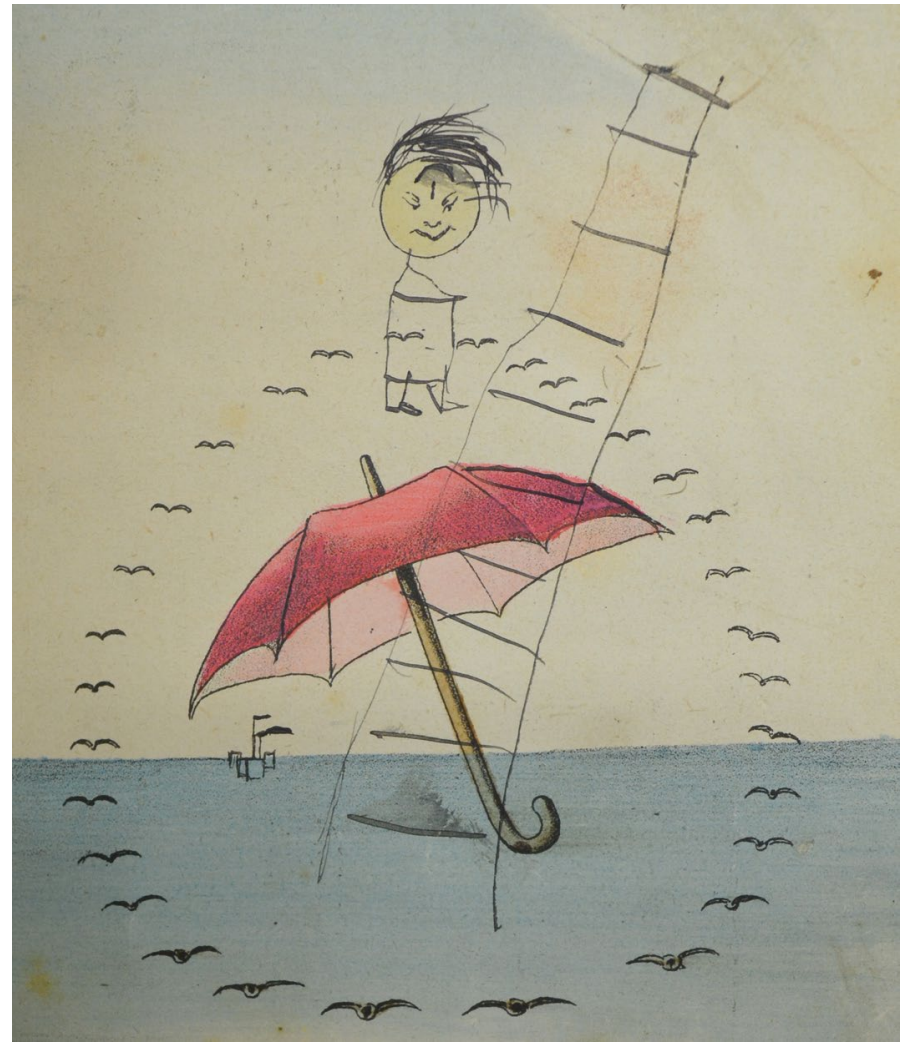

Fig. 1 Anthropomorphization of animals or inanimate objects ([Anonym 1890], unpag.; Göttingen Collection S 2b 73)

book Mecki und die 40 Räuber (Rhein and Petersen 1960). Its former owner marked the colorfully illustrated volume with spacious circle movements (cf. Fig. 3). Not always but in most cases, both forms of painting in seem to try to fill a vacant or less intensively colored space. We suggest that these actions might be based on the embodied experience that things have colors. The fact that things, i.e. objects in the world, do not only have shape and extension is a generalization which can only be made on the basis of perception experiences (cf. Johnson 1999, pp. 86-88; Shapiro 2011, pp. 81-85), a generalization that white spaces and especially black-and-white-drawings do not comply with. Since small children are not yet able to completely recognize the fictional character of paintings (cf. Corriveau et al. 2009; Weisberg and Sobel 2012; Rakoczy 2008), a desire could be to give these spaces, or things, colors. In addition, there might always be individual aesthetic preferences.

Concerning different ways of reception, it is also worth mentioning that young children have a different understanding of fictionality than adults, and that their understanding of fiction even depends on the emotions displayed in the books (cf. Carrick and Ramirez 2012). This is especially noticeable when it comes to 


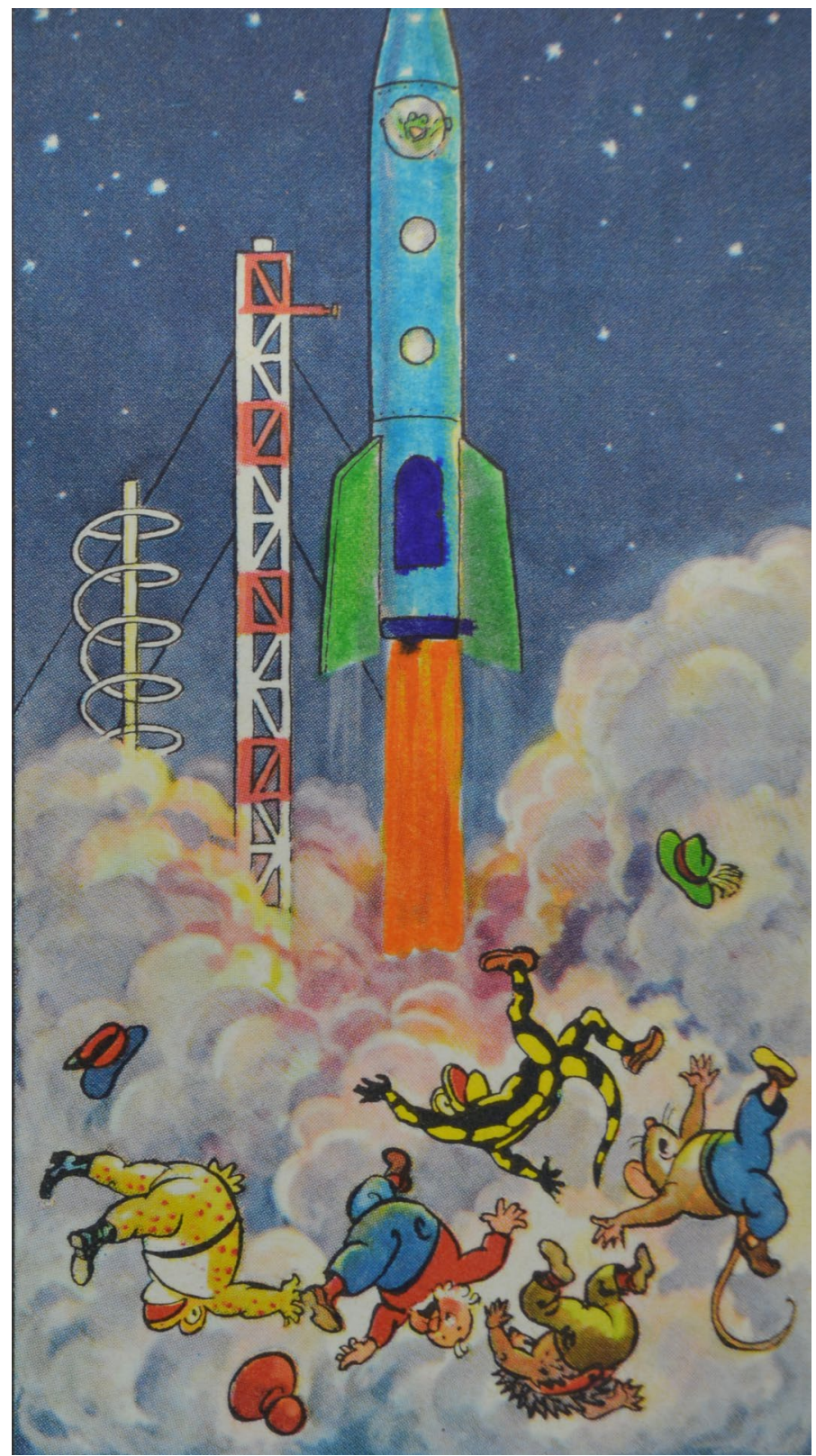

Fig. 2 Intensification of colors (Schubel 1974, p. 51; Göttingen Collection S 22a 45)

crossing things out or marking things with a cross. The depicted characters or objects are positively or negatively evaluated by a corresponding intervention of the child in the materiality. The young recipients also relate themselves to the event or character and thus enter an interpersonal relationship with the characters 


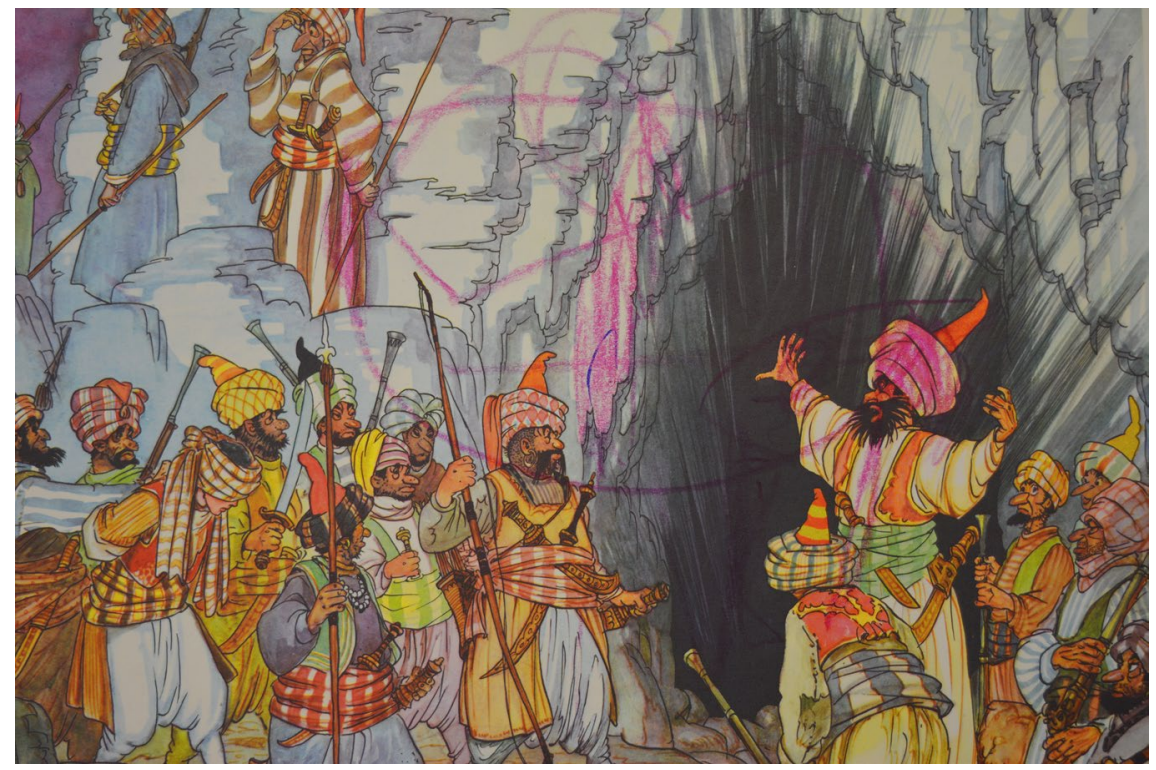

Fig. 3 Circle movements (Rhein and Petersen 1960, unpag.; Göttingen Collection S 22a 28)

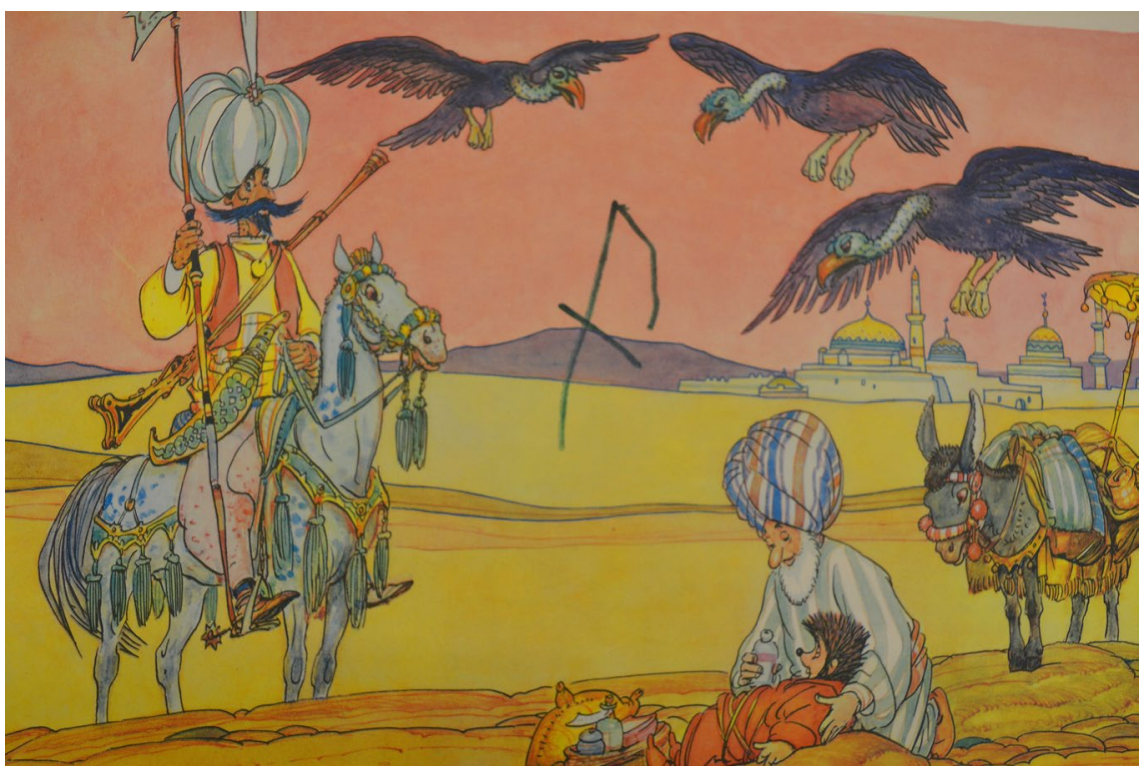

Fig. 4 Cross mark (Rhein and Petersen 1962, unpag.; Göttingen Collection S 22a 21) 


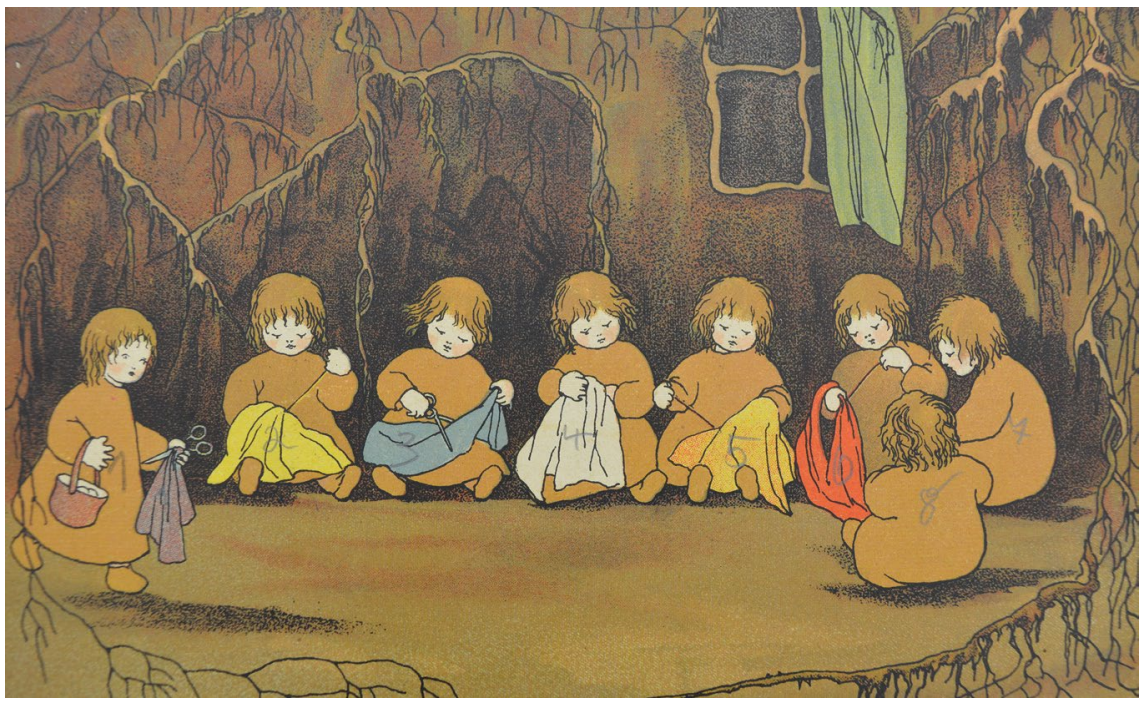

Fig. 5 Numbering (Olfers 1965, unpag.; Göttingen Collection Stacks)

or events, which means they do not only become part of the diegesis by immersion but also evaluate specific aspects of it. In the case of the Göttingen copy of Mecki und Sindbad (Rhein and Petersen 1962), personal references to individual characters or possibly even situations were made by marking them with a cross (cf. Fig. 4). Further research has to clarify whether such marks can also express more complex issues than positive or negative references alone. A copy of Sybille von Olfers' Etwas von den Wurzelkindern (Olfers [c. 1965]) exemplifies another form of image reference where the characters were given numbers (cf. Fig. 5). Apparently, the young recipient used numbers in order to open up the world of the Wurzelkinder in order to find systematizing access to it. What is more, writing or drawing is often added to vacant spaces in children's books as well. Here, the recipient subject's reference to the text is much less distinct than, for example, in the case of marking or crossing out. Often children fill blank pages or margins with writing exercises, their own name or occasional notes. It is uncertain whether the owner's marks are the starting point for such additions, or whether it is due to the extension of the book's text by one's own writing.

Another way of modifying the material, especially in young children, is probably much less likely due to intended actions that refer to what is depicted: the tearing out of pieces of paper or the ripping of pages. In addition, rare cases can be found in which material was added by gluing. Since the ripping of book pages is a frequent form of object reception in young children, 'rip-proof' picture books made of sturdier cardboard have been developed quite early. Since the technical production permits it, the pages of such works are often also coated with plastic, so that painting is easier to remove or cannot be applied at all. Both attempts to prevent the modification classified as destruction become manifest in a particularly impressive manner, 
for example, in the picture book Thomas im Dorf by Hilde Heyduck-Huth (1929-; Heydruck-Huth 1968). The illustrations are kept naïve and deliberately approach children's drawings. At the same time, however, the book is presented as a (finished) work of art, which - as was the case with Meggendorfer-does not involve children's intervention in materiality. The selection of other basic materials such as cotton or felt, as it is present in the above-mentioned Ri-Ra-Rasselbuch by NeubacherFesser, should be viewed in this context.

As a rule, each of the mentioned material treatments in the course of the child's reception requires that the children are alone with the books. Since adults usually consider the portrayed child-like receptions and interventions in materiality as the destruction of the cultural object worth of protection, they will prevent corresponding modifications. Until well into the 19th century such an unguided reception would have been the exception because children's books were primarily written with a pedagogical intent and — as any reading — were not read quietly and alone, but aloud (cf. Schön 1987). Possibly, in addition to pedagogy based on instruction and supervision, the high-quality design and the considerable price were reasons why children were not left alone with the volumes. For later times and the extension of the reception to other social classes, it should be noted that the tools for a materialmodifying reception were often unavailable: especially in households that could afford only a few books, the children might not have had access to pens, especially not to crayons, and to craft utensils.

\section{Materiality in children's books and reception aesthetics}

We believe that such forms of reception, which influence the materiality of books, must be considered as specifics to children's literature. Moreover, we assume that research on children's books should suppose an extended notion of materiality that includes such reception practices as constitutive of children's literature.

Roland Barthes had already provided the basis for the interlinking of production and materiality in his 1973 essay Variations sur l'écriture. In the following, we will extend it to a connection between reception and materiality, which we consider specific for children's literature. Barthes recognizes the writing, or the physical dimension of the author's textualization, as a key act in the emergence of literature (cf. Barthes 1994, p. 1535). In doing so, he directs the focus from a supposedly purely mental activity to materiality and corporality, and gives this process the name scription, "ce geste par lequel la main prend un outil [...], l'appuie sur une surface, y avance en pesant ou en caressant et trace des formes régulières, récurrentes, rythmées" (ibid.). The materiality of the described material is also important to Barthes, "parce que la texture de la matière (son glacé ou son rugueux, sa dureté ou sa mollesse, sa couleur même) oblige la main à des gestes d'agression ou de caresse" (ibid, p. 1567). Thus, the selection of the paper, but ultimately also that of the writing utensil, is decisive for the production of the text: materiality determines what can arise in the hereby given and pre-structured space (cf. Pichler and Ubl 2007). For Barthes, the scription is closely related to the écriture, which he has redefined several times in the course of his work. Essentially, however, écriture means a specific 
literary way of writing that turns a system of signs into literature, not a physical act, but a semiotic one.

Barthes' concept was amplified by Julia Kristeva, who emphasizes the importance of reception and introduces the compound écriture-lecture (Kristeva 1969, p. 115). Kristeva also uses Michail Bakhtin's concept of dialogue and understands the literary text as "un double" (ibid.), namely, one that is not only produced in the author's écriture but is also constituted in the reader's lecture. Thus, the author is considered a reader as well: the literary text stands for Kristeva in historical and social contexts, which the author himself must read in order to encode the own literary text (ibid., p. 120). In this sense too, the écriture-lecture forms an inseparable unity whose analysis Kristeva approaches through her theory of intertextuality.

The connection between reading and writing is thus strongly emphasized in Kristeva but refers to the non-material processes of production. Materially conceived is only the scription by Barthes, which is not incorporated by Kristeva in the 'double' écriture-lecture. Much more, the importance of the text's materiality is negated and the textual substrate as a semiotic-material anchor is replaced by a network of intertextual references. Looking at children's literature, we venture to suggest a connection between scription and lecture below.

The provided examples from the Göttingen Collection of Historical Children's and Youth Literature clearly show how closely the child's own corporality, the materiality of the book and its modification are connected, especially in the child-like reception of books. This observation points to a field that has come into scientific focus only in recent years, which, however, still finds little attention, especially in literary studies: the theory of embodied cognition. The term 'embodiment' summarizes many questions and approaches from different disciplines, starting from the basic assumption that cognitive processes are not just related to neuronal activities, but include the whole body. Learning processes are also understood as whole-body engagement (e.g. Skulmowski and Rey 2018). Fundamental here is the assumption that bodily experiences form specific so-called conceptual metaphors that structure thinking (cf. Lakoff and Johnson 1999) and thus also influence learning processes (cf. Gallagher and Lindgren 2015). Embodied conceptual metaphors are not necessarily present in linguistic metaphors, but rather form a cognitive substructure (cf. Casasanto and Gijssels 2015).

From the perspective of children's literature, it becomes clear how the specific forms of reception could emerge: the materiality of the book and its exploration present a new embodied experience for children. At the same time, the children approach the objects with their already formed presumptions about the items. These presumptions can be confirmed on the object so that there is a world-to-mind directed impact. Especially in fictional works and books, which differ from objects of the actual world by their structural abstractness, some assumptions of the embodied experience are not to be confirmed, e.g. in relation to the illustrations, that things have a color or-even more fundamentally - that things have extent. Then there may be a mind-to-world directed impact that seeks to add the materiality of the actual world to the non-material fictional world.

Thus, one could argue following Barthes and Kristeva, that the child-like reception of books is based on a lection that is conceptualized as the bodily and material 
side of reception. In the lection, there is an amalgamation of scription and lecture, which is applied here to the reception process. The child co-writes-also in the narrower sense-the book by their reception, not only in the sense of an écriture-lecture but also through the bodily performed interventions in the materiality of the book. For the child, this lection is performed in the course of understanding and systematization of the world-particularly obvious in the example of numbering characters-and it thus always carries in itself a leçon, an experiential unit of embodied learning. Consequently, the child's scription also goes beyond the processes of adult's reading, which of course include the brain, eyes, hands, ears, and indeed the entire posture (cf. Mackey 2018), but do not become apparent in the modification of materiality.

In summary, we argue on the basis of the concept of lection, which terminologically pools specific forms of reception of children's books, for an augmented concept of materiality in children's literature. In particular, picture book research and research on books for younger children should not assume an understanding of materiality that reproduces a concluded concept of the work, but rather take the concept of écriture-lecture seriously and apply it to a material basis. With the production of the author, the illustrator/designer, and the printer/manufacturer, the materiality of the children's book is not fixed and finished, it is constantly changing through the lection of the child recipient. Also regarding the concept of work, children's literature thus has a boundary-dissolving effect.

\section{Author contributions Not applicable.}

Funding The authors received no financial support for the research, authorship, and/or publication of this article. Open Access funding provided by Projekt DEAL.

Availability of data and materials Not applicable.

Code availability Not applicable.

\section{Compliance with ethical standards}

Conflict of interest Both authors declare that they have no conflict of interest.

Open Access This article is licensed under a Creative Commons Attribution 4.0 International License, which permits use, sharing, adaptation, distribution and reproduction in any medium or format, as long as you give appropriate credit to the original author(s) and the source, provide a link to the Creative Commons licence, and indicate if changes were made. The images or other third party material in this article are included in the article's Creative Commons licence, unless indicated otherwise in a credit line to the material. If material is not included in the article's Creative Commons licence and your intended use is not permitted by statutory regulation or exceeds the permitted use, you will need to obtain permission directly from the copyright holder. To view a copy of this licence, visit http://creativecommons.org/licen ses/by/4.0/. 


\section{References}

[Anonym 1890]: Der rote Wunderschirm. Neu-Ruppin: Kühn.

Bäni Rigler, P. (2019). Bilderbuch - Lesebuch - Künstlerbuch. Elsa Beskows Ästhetik des Materiellen. Tübingen: Narr.

Bär, J. A., Mende, J.-K., \& Steen, P. (2015). Literaturlinguistik - eine Einführung. In J. A. Bär, J.-K. Mende, \& P. Steen (Eds.), Literaturlinguistik - philologische Brückenschläge (pp. 7-18). Frankfurt a. M.: Lang.

Barthes, R. (1994). Variations sur l'écriture [1973]. In: Barthes, Roland: EEuvres complètes. 2, 19661973. Éd. établie et présentée par Éric Marty (pp. 1535-1574). [Paris]: Éd. du Seuil.

Bauer van Wechem, R. (1988). Kinder- und Jugendliteratur betrachtet aus einer entwicklungspsychologischen und pädagogischen Optik. Paideia Międzynarodowy Rocznik Pedagogiczny, 14, 51-62.

Bausinger, H. (1987). Kultur für Kinder - Kultur der Kinder. In K. Köstlin (Ed.), Kinderkultur. 25. Deutscher Volkskundekongreß in Bremen vom 7. bis 12. Oktober 1985 (pp. 11-18). Bremen: Focke-Museum.

Berner, R. S. (2007). Das Winter-Wimmel-Leporello. Hildesheim: Gerstenberg.

Bertuch, F. J. (1790). Bilderbuch Für Kinder. Enthaltend eine angenehme Sammlung von Thieren, Pflanzen, Blumen, Früchten, Mineralien, Trachten und allerhand andern unterrichtenden Gegenständen aus dem Reiche der Natur, der Künste und Wissenschaften; alle nach den besten Originalen gewählt, gestochen, und mit einer kurzen wissenschaftlichen, und den Verstandes-Kräften eines Kindes angemessenen Erklärung begleitet; Seiner Durchlaucht dem Herrn Erbprinzen Carl Friedrich, zu Sachsen Weimar und Eisenach zugeeignet (Vol. 1). Weimar: Industrie Comptoir.

Bolter, D. J. (2001). Writing space. Computers, hypertext, and the remediation of print (2nd ed.). Mahwah: Erlbaum.

Carrick, N., \& Ramirez, M. (2012). Preschoolers' fantasy-reality distinctions of emotional events. Journal of Experimental Child Psychology, 112(4), 467-483.

Casasanto, D., \& Gijssels, T. (2015). What makes a metaphor an embodied metaphor? Linguistics Vanguard, 1(1), 327-337.

Corriveau, K. H., Kim, A. L., Schwalen, C. E., \& Harris, P. L. (2009). Abraham Lincoln and Harry Potter: Children's differentiation between historical and fantasy characters. Cognition, 113(2), 213-225.

Field, H. (2015). The story unfolds. Intertwined space and time in the Victorian Children's Panorama. In M. S. Cecire, H. Field, K. M. Finn, \& M. Roy (Eds.), Space and place in children's literature, 1789 to the present (pp. 165-188). Farnham, Burlington: Ashgate.

Finkelstein, D., \& McCleery, A. (2005). An introduction to book history. New York: Routledge.

Gallagher, S., \& Lindgren, R. (2015). Enactive metaphors. Learning through full-body engagement. Educational Psychology Review, 27(3), 391-404.

Hallberg, K. (1982). Literaturvetenskapen och bilderboksforskningen. Tidskrift för litteraturvetenskap, 11(3-4), 163-168.

Heydruck-Huth, H. (1968). Thomas im Dorf. Ravensburg: Maier.

Hombrecher, H., Jessen, B., \& Bräuer, C. (2019) „Spiegel der Zeit“. Die Göttinger Kinder- und Jugendbuchsammlung Wehner. $k j l \& m, 71(1), 85-89$.

Johnson, M. L. (1999). Embodied reason. In G. Weiss \& H. F. Haber (Eds.), Perspectives on embodiment. The intersections of nature and culture (pp. 81-102). New York: Routledge.

Kayser, B. (2011a). Technik und Innenleben von Spiel- und Verwandlungsbüchern. In W. Wangerin (Ed.), Der rote Wunderschirm. Kinderbücher von der Frühaufklärung bis zum Nationalsozialismus (pp. 144-146). Göttingen: Wallstein.

Kayser, B. (2011b). Komm mit zum Handwerksmann!. In W. Wangerin (Ed.), Der rote Wunderschirm. Kinderbücher von der Frühaufklärung bis zum Nationalsozialismus (p. 150). Göttingen: Wallstein.

Kayser, B. (2011c). 142 Voitěch Kubašta: [Polarstation. - Prag: Artia, ca. 1965]. In: Wangerin, W. (Ed.): Der rote Wunderschirm. Kinderbücher von der Frühaufklärung bis zum Nationalsozialismus (p. 151). Göttingen: Wallstein.

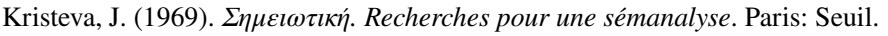

Kroucheva, K., \& Schaff, B. (2013). Einleitung. In K. Kroucheva \& B. Schaff (Eds.), Kafkas Gabel. Überlegungen zum Ausstellen von Literatur (pp. 7-22). Bielefeld: Transcript.

Krutzler, G. (2011). Kult und Tabu. Wahrnehmungen der Germania bei Bonifatius. Wien, Berlin: Lit.

Kubašta, V. [Polarstation. Prag: Artia ca. 1965]. 
Kümmerling-Meibauer, B. (2011). Emergent literacy and children's literature. In B. KümmerlingMeibauer (Ed.), Emergent literacy Children's books from 0 to 3 (pp. 1-14). Amsterdam: Benjamins.

Kümmerling-Meibauer, B., \& Meibauer, J. (2018). Picturebooks and cognitive studies. In B. Kümmerling-Meibauer (Ed.), The Routledge companion to picturebooks (pp. 391-400). New York: Routledge.

Lakoff, G., \& Johnson, M. (1999). Philosophy in the flesh. The embodied mind and its challenge to western thought. New York: Basic Books.

Lambert, M. D. (2018). Picturebooks and page layout. In B. Kümmerling-Meibauer (Ed.), The Routledge companion to picturebooks (pp. 28-37). New York: Routledge.

Mackey, M. (2018). The child's reading body. In R. Harde \& L. Kokkola (Eds.), The embodied child. Readings in children's literature and culture (pp. 175-190). New York, London: Routledge.

Maziarczyk, G. (2013). The novel as book. Textual materiality in contemporary fiction in English. Lublin: Wydawnictwo KUL.

McGann, J. (1991). The textual condition. Princeton: Princeton University Press.

Meggendorfer, L. (1873). Lebende Bilder (4th ed.). München: Braun \& Schneider.

Messerli, S. (2005). Die Knickkante im Bilderbuch. Die Menschen im Meer als dialektisches Material. In C. Lötscher \& I. Tomkowiak (Eds.), Stofflichkeiten. Aspekte der Materialität in populären Literaturen und Medien (pp. 9-19). Zürich: Universität Zürich - ISEK.

Mitgutsch, A. (1980). Das Riesenbilderbuch. Ravensburg: Maier.

Mittler, E., \& Wangerin, W. (Eds.). (2004). Nützliches Vergnügen. Kinder- und Jugendbücher der Aufklärungszeit aus dem Bestand der Niedersächsischen Staats- und Universitätsbibliothek Göttingen und der Vordemann-Sammlung. Göttingen: Niedersächsische Staats- und Univ.-Bibliothek.

Montanaro Staples, A. (2018). Pop-up and movable books. In B. Kümmerling-Meibauer (Ed.), The Routledge companion to picturebooks (pp. 180-190). New York: Routledge.

Müller-Wille, K. (2020). Das Lesen neu erfinden. Zu Aspekten der Materialität in der Kinder- und Jugendliteratur. In U. Dettmar, C. Roeder, \& I. Tomkowiak (Eds.), Schnittstellen der Kinder- und Jugendmedienforschung. Aktuelle Positionen und Perspektiven (pp. 11-26). Stuttgart: Metzler.

Neubacher-Fesser, M. (2018). Mein Ri-Ra-Rasselbuch. Ravensburg: Ravensburger.

Oetken, M. (2008). Bilderbücher der 1990er Jahre. Kontinuität und Diskontinuität in Produktion und Rezeption. Dissertation, Universität Oldenburg 2008. Online. Retrieved July 2, 2019: http://oops. uni-oldenburg.de/747/1/oetbil08.pdf.

Op de Beeck, N. (2018). Picture-text-relationships in picturebooks. In B. Kümmerling-Meibauer (Ed.), The Routledge companion to picturebooks (pp. 19-27). New York: Routledge.

Pichler, W., \& Ubl, R. (2007). Vor dem ersten Strich Dispositive der modernen und vormodernen Zeichnung. In W. Busch, O. Jehle, \& C. Meister (Eds.), Randgänge der Zeichnung (pp. 231-255). München: Fink.

Rakoczy, H. (2008). Taking fiction seriously. Young children understand the normative structure of joint pretence games. Developmental Psychology, 44(4), 1195-1201.

Rhedin, U. (1992). Bilderboken. På väg mot en teori. Stockholm: Alfabeta.

Rhein, E., \& Petersen, W. (1960). Mecki und die 40 Räuber. Sein neunter märchenhafter Reisebericht. Aufgeschrieben von ihm selbst. Hamburg: Hammerich \& Lesser.

Rhein, E., \& Petersen, W. (1962). Mecki und die 40 Räuber. Sein 11. Märchenhafter Reisebericht. Aufgeschrieben von ihm selbst. Hamburg: Hammerich \& Lesser.

Rumpf, M. (2011). Der rote Wunderschirm. In W. Wangerin (Ed.), Der rote Wunderschirm. Kinderbücher der Sammlung Seifert von der Frühaufklärung bis zum Nationalsozialismus. Göttingen: Wallstein.

Schachenmeier, H., \& Scheel, M. (1944). Kommt mit zum Handwerksmann! Ein Spielbilderbuch. BadenBaden: Stuffer.

Schön, E. (1987). Der Verlust der Sinnlichkeit oder die Verwandlungen des Lesers. Mentalitätswandel um 1800. Stuttgart: Klett-Cotta.

Seidmann-Freud, T. (1935). The magic boat. A book to turn, move and alter. Berlin: Stuffer.

Schubel, H. (1974). Lurchis gesammelte Abenteuer (Vol. 2). Kornwestheim: Salamander AG.

Shapiro, L. (2011). Embodied cognition. London: Routledge.

Skulmowski, A., \& Rey, G. D. (2018). Embodied learning. Introducing a taxonomy based on bodily engagement and task integration. Cognitive Research: Principles and Implications, 3(1). Retrieved July 2, 2019, https://cognitiveresearchjournal.springeropen.com/articles/10.1186/s4123 5-018-0092-9.

Veryeri Alaca, I. (2018). Materiality in picturebooks. In B. Kümmerling-Meibauer (Ed.), The Routledge companion to picturebooks (pp. 59-68). New York: Routledge. 
Von Olfers, S. (1965). Etwas von den Wurzelkindern. Eßlingen: Schreiber.

Wangerin, W. (Ed.). (2011). Der rote Wunderschirm. Kinderbücher von der Frühaufklärung bis zum Nationalsozialismus. Göttingen: Wallstein.

Wassiltschenko, J. (2018). Sammlung historischer Kinder- und Jugendliteratur. In U. Beisiegel (Ed.), Die Sammlungen, Museen und Gärten der Universität Göttingen (2nd ed., pp. 50-51). Göttingen: Universitätsverlag.

Weisberg, D. S., \& Sobel, D. M. (2012). Young children discriminate improbable from impossible events in fiction. Cognitive Development, 27(1), 90-98.

Publisher's Note Springer Nature remains neutral with regard to jurisdictional claims in published maps and institutional affiliations. 